\title{
Study of biodigester design for fuel and fertilizer
}

\author{
Omprakash Sahu, Yasabie Abatneh \\ Department of Chemical Engineering, KIOT, Wollo University, Ethiopia
}

\section{Email address:}

ops0121@gmail.com(O.Sahu)

\section{To cite this article:}

Omprakash Sahu, Yasabie Abatneh. Study of Biodigester Design for Fuel and Fertilizer. International Journal of Renewable and Sustainable Energy. Vol. 2, No. 4, 2013, pp. 147-152. doi: 10.11648/j.ijrse.20130204.13

\begin{abstract}
Design of a biogas plant supplying energy for the students' cafeteria while utilizing the abundant human waste has been done with an aim of significantly reducing wood consumption. Major fuels used in the cafeteria to prepare three meals per day for 3500 student's electricity, Naphtha, and fuel wood. Three years data have been examined to study the pattern of the energy demand, amounts, and price of the energy sources with emphasis on wood. Feed stock potentials, its compositions, nearness to the cafeteria, and various other criteria have been considered in the site selection. It has been found that technically possible to produce as much as $30 \mathrm{cu} / \mathrm{m} /$ day biogas in the selected site contributing to $44.5 \%$ reduction in wood consumption. Performance of digesters in the climate and weather condition of the region for similar feedstock has been assessed to determine the appropriate digester model. Chinese fixed dome and Deenbandhu models are common and have shown good performance. Detail design and dimensioning of the digester have been done. Financial feasibility has been evaluated using NPV (net present value), internal rate of return (IRR) and simple payback method. Positive NPV, 18.5\% IRR and a payback period of 6.27 years have been calculated indicating the financial feasibility.
\end{abstract}

Keywords: Fixed Dome, Biogas, Digester, Retention Time

\section{Introduction}

Biogas technology is being used both at small scales and large scales in Ethiopia. Due emphasis has also been given for applications for rural people as means of reducing deforestation, improving indoor air pollution and reducing woman's time and effort in fuel collection. Applications in Hospitals, prisons and schools are also seen in major parts of the country. Plans also exist for wide spread use of the technology. For instance the Amhara prison administration has allocated significant budget for installation of biogas plants throughout the prisons in the region. [4] Application of biogas technology in Universities is very limited in the country. However research on biogas and production technologies are observed in some Universities. Currently there is no University who has applied biogas technology for use in reducing its fuel consumptions. The rising number of students and fuel cost and scarcity is forcing universities spent a lot to cook food three times a day for larger population. Additionally, due to commonly used traditional waste treatment technologies like septic tank permanent environmental solution is a must. The main research question emanates from these facts. How can biogas plants contribute to reduced energy cost and eliminate environmental problems in universities while abundant feed stock.

Anaerobic digestion has been suggested as an alternative method of removing the high concentration organic waste. Several research groups have developed anaerobic digestion processes using different organic substrates [5-7]. The advantages of such processes over conventional aerobic processes are a low energy requirement for operation, a low initial investment cost and a low sludge production [8]. In addition, the anaerobic digestion process produces biogas, which can be used as a clean renewable energy source $[9,10]$. In Europe, increasing numbers of biogas plants (BGPs) employing anaerobic digestion use food waste and manure as energy sources. Anaerobic digestions can be developed at different temperature ranges including mesophilic temperatures (approximately $35^{\circ} \mathrm{C}$ ) and thermophilic temperatures ranging from $55^{\circ} \mathrm{C}$ to $60^{\circ} \mathrm{C}$. Conventional anaerobic digestion is carried out at mesophilic temperatures, that is, $35-37^{\circ} \mathrm{C}$. Several new processes have been reported for upgrading sludge digestion using thermophilic anaerobic digestion $\left(55^{\circ} \mathrm{C}\right)$ and these represent an important alternative to mesophilic anaerobic digestion $\left(35^{\circ} \mathrm{C}\right)[11,12]$. The thermophilic 
temperature range is worth considering because it will lead to give faster reaction rates, higher gas production, and higher rates of the destruction of pathogens and weed seeds than the mesophilic temperature range. However, the thermophilic process is more sensitive to environmental changes than the mesophilic process. Two main technologies have been used for the rapid treatment of organic fraction of municipal solid wastes (OFMSW): sequential leach-bed anaerobic processes [13] and CSTR reactors [14] or Batch systems [15]. Both technologies have very simple designs and there are numerous reports on their use [16]. However, the CSTR systems are the least expensive solid waste digesters for simplest designs. It is superior and more economical than other competing technologies because it is grown in a similar anaerobic environment [17]. The system has high potential for application in developing countries [15].

Also, the large majority of industrial applications use one-stage systems and these are evenly split between "dry" systems (wastes are digested as received) and "wet" systems (wastes are slurred to about $12 \%$ total solids). However, the "dry" designs or high-solid [8] have proven reliable due to their higher biomass concentration, controlled feeding and spatial niches [18, 19]. Moreover, from a technical viewpoint, the "dry" systems are more robust and flexible than "wet" systems. Municipal solid waste (MSW) is a serious problem for urban communities. Organic solids are present in very large quantities as products or waste from agriculture, the food industry and market waste. Spain generates approximately 24 million tonnes of MSW annually. According to the data published by the National Plan of Urban Wastes (NPUR, 2000-2006), $40-45 \%$ of total MSW is the organic fraction of municipal solid waste (OFMSW). The composition of OFMSW is influenced by several factors, including regional differences, climate, collection frequency, season, cultural practices, as well as changes in composition [20]. At this respect, numerous papers have focused on aspects of anaerobic digestion biodegradation of the OFMSW according to its origin: e.g., market waste [21], fruit and vegetable [22], household waste [23], food waste [24], kitchen waste [25], biowaste [6] and organic fraction of municipal solid waste (OFMSW) [26]. In this regard an effort has been made design the anaerobic biodigester for the cafeteria.

\section{Design Parameter}

Following is a discussion of the most important parameters which must be considered in the design of an anaerobic digestion system:

i) Temperature - Three ranges exist for anaerobic digestion:

- Psychrophilic range - Between $5^{\circ}$ and $25^{\circ} \mathrm{C}$; characterized by slower methane production and longer retention times.
- Mesophilic range - Between $30^{\circ}$ and $40^{\circ} \mathrm{C}$; the most widely used of the three [27], this range balances heating costs with methane production.

- Thermophilic range - From $50^{\circ}$ to $60^{\circ} \mathrm{C}$; produces the most methane but is also the most sensitive, due to fewer bacterial species in existence.

Once a stable temperature is reached, fluctuations should be kept within $5^{\circ} \mathrm{C}$ to avoid killing the desired bacteria [28] Thermophilic tolerance is generally less than that of lower temperatures [29]. Each temperature range at which the digester can be operated has its own advantages. The thermophilic process has been found to be superior to the mesophilic process from an energy balance and, thus, "profit" point of view [30]. Thermophilic digesters usually achieve better degradation of long-chain fatty acids, have a shorter retention time, and require less biomass compared to the quantity of methane produced. The thermophilic process also achieves higher pathogen and weed seed destruction than the mesophilic process alone [31]. However, the risk of ammonia inhibition is greater and more energy is required to operate a thermophilic digester. Thermophilic processes are considered to be more prone to instability than mesophilic due to fluctuations in input quality [32]. However, in a study of major centralized biogas plants in Denmark, Ahring [30] found no significant difference in volatile fatty acid concentrations between the two processes and conceded that the start-up time of thermophilic digesters is longer than that of a mesophilic reactor due to the low numbers of thermophilic bacteria in organic waste. Most of the agricultural digesters in the United States are mesophilic [33]. The process is slightly more stable and adaptable to fluctuations in feedstock quality than thermophilic. The lower heating requirements of mesophilic temperatures translate into lower costs. Residence time should be at least 15 days for adequate digestion [32].

Psychrophilic digesters require a solids retention time approximately twice as long as mesophilic. These digesters require the least amount of energy input. Biogas production is slow but gas quality and other parameters indicate favorable process stability [29]. These systems are commonly found in the form of a covered lagoon and, as such, they are usually subject to fluctuations in temperature.

ii) Loading Rate - This is expressed as the weight of volatile solids (VS) per unit of volume of digester capacity per unit of time. Loading rates typically range from 1.2 to $11.0 \mathrm{~kg} \mathrm{VS} / \mathrm{m} 3 / \mathrm{d}$ for various types of digesters and manure sources [34]. While high loading rates use the digester volume more efficiently, they also increase solids concentration, retention time and alkalinity, which must be taken into consideration.

iii) Retention Time - The Hydraulic Retention Time (HRT) and Solids Retention Time (SRT) are the average lengths of time the liquid or solid portion of manure remains in the digester. Generally, the lower the operating temperature (e.g. psychrophilic digestion) the higher the retention time that is needed. 
iv) Solids Concentration- Normally reported as the percentage dry matter and the volatile solid percentage of that dry matter, the solids concentration is necessary to determine the loading rate. The solids concentration also helps to determine the most suitable type of digester.

v) Alkalinity and $\mathrm{pH}$ - Optimum $\mathrm{pH}$ conditions for methanogenic bacteria range from 6.4 to 7.6 [29]. Other bacterial species are more tolerant to $\mathrm{pH}$ levels outside of this range.

\section{Types of Biodigester}

The reactor dimensions and biogas potential depends on:

- The type of substrates to be digested

- The quantity of each in metric tons per year

- The total solid content in percentage

- Total solids content (TS) $=100(\%)$ - water content $(\%)$

- The organic content in percentage: Organic dry matter content is determined by incinerating the dried sample at $550^{\circ} \mathrm{C}$ for six hours and weighing the remaining ashes.

- Organic content $(O D M)=($ mass of TS $(g)$-mass of ashes (g)x100/mass of TS(g)

- The size of the digester $(\mathrm{Vd})$ is determined by the retention time (RT) and the daily substrate input in $\mathrm{m}^{3}$ (Sd).

- The following formula can be used in order to calculate the appropriate volume:

$\mathrm{Vd}=\mathrm{Sd} \times \mathrm{RT}$

Several different systems have been designed for anaerobic digestion. Following are basic descriptions of the more popular systems used on farms.

\subsection{Plug Flow System}

The plug flow system usually takes the form of a long concrete tank with a slight grade over the length. Influent is either continuously or intermittently added to one end and flows by gravity to the opposite end. The contents are not mixed mechanically. The retention time is thus a function of channel length, channel grade, and the loading rate. The plug flow digester is best suited for manure with a higher solids content (11 to $13 \%$ total solids) such as that of a dairy operation [35]. Figure 4 shows the main elements of a plug flow digester system.

\subsection{Complete Mixed System}

Also known as a Completely Stirred Tank Reactor (CSTR), the complete mixed system is most commonly a circular tank with a mechanical agitator. The mixing prevents settling and maintains contact between bacteria and the manure. It also helps maintain a uniform temperature [37]. Electricity input costs are higher due to the intermittent mixing of the digester. However, the mixing can cause foaming in the tank, which is undesirable because it occupies digester volume and can clog gas lines. Complete mix systems are able to handle the widest range of solids concentrations (3 to $10 \%$ total solids) [35]. Influent is often added to the digester as effluent is excreted in small quantities at regular intervals. Therefore the retention period of manure in a complete mix digester is not necessarily uniform.

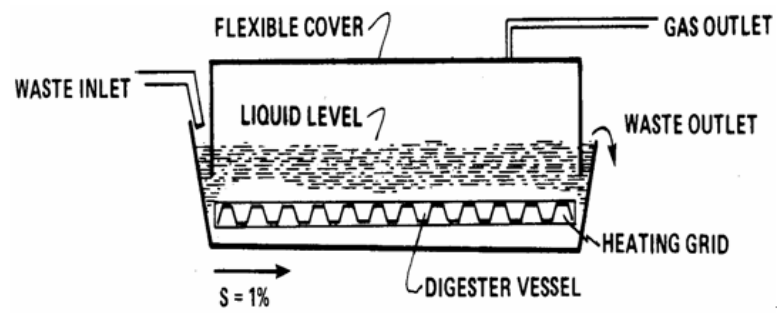

Fig 1. Typical plug flow digester system [36]

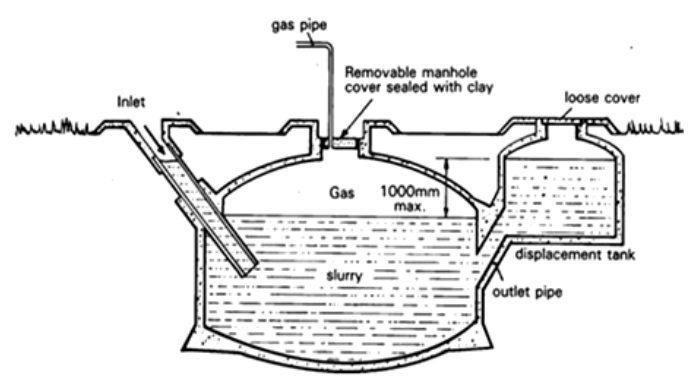

Fig 2. Fixed Dome Biogas Digestor [36]

\section{Digester Design}

\subsection{Digester Selection}

Common digester types in developing countries are fixed dome and floating drum plants. Fixed dome plants are made entirely below the ground saving space and being less affected by damage and daily temperature fluctuations. They are the most commonly built digester in the hot climate of the region. In floating drum plants the gas holder is made of stainless steel which contributes to the expensiveness of the digester but its operation is easy to understand than fixed dome plants since the gas holder is above the ground. Among fixed dome types Deenbadhu and Chinese fixed dome represent the most built and well performing digesters in the region. For instance digesters in Felegehiwot Hospital (65cu.m digester) and Bahir Dar Prison (100cu.m digester) have Deenbadhu type fixed dome plants which are serving a lot. [4] Biogas digester is Addis Zemen (a small city near Bahir-dar) prison has a well operational fixed dome digester.

\subsection{Sizing of Digester}

a) Active slurry volume (Vs)

For normal retention time of HRT $=40$ days [1] and waste amount of $\mathrm{W}=400 \mathrm{~kg} /$ day,

$\mathrm{Vs}=2 * \mathrm{HRT}^{*} \mathrm{~W} / 1000 \mathrm{cu} . \mathrm{m}$

$\mathrm{Vs}=32 \mathrm{cu} . \mathrm{m}$

b) Gas production $\mathrm{G}$ 
Specific gas yield of human waste $\mathrm{Gs}=0.03 \mathrm{cu} . \mathrm{m} / \mathrm{kg}$ [1] and total amount of waste for

1000 people with $0.4 \mathrm{~kg} /$ person/day [1] is,

$\mathrm{G}=1000 * 0.4 * 0.03=30 \mathrm{cu} . \mathrm{m} /$ day

c) Water volume

5lit cans are used during toilet cleaning and 0.75lit cans are used for flashing after use.

Hence the total volume of water is, 0.75 lit $/$ person $* 1000+5$ lit $/$ toilet $* 30$ toilet $=900$ lit

For retention time of 40 days water volume is $36 \mathrm{cu} . \mathrm{m}$

Total digester volume $32+30+36=98 \mathrm{cu} . \mathrm{m}$

Shown in table 1 are the dimensions of 100cu.m biogas pant as determined by Selam technical and vocational Center (STVC); contractors on biogas plants. The dimensions refer to digester design shown on figure 2 .

Table 2 shows the bill of quantities as specified by STVC [38] and price of quantities as determined by market Survey during October 2008

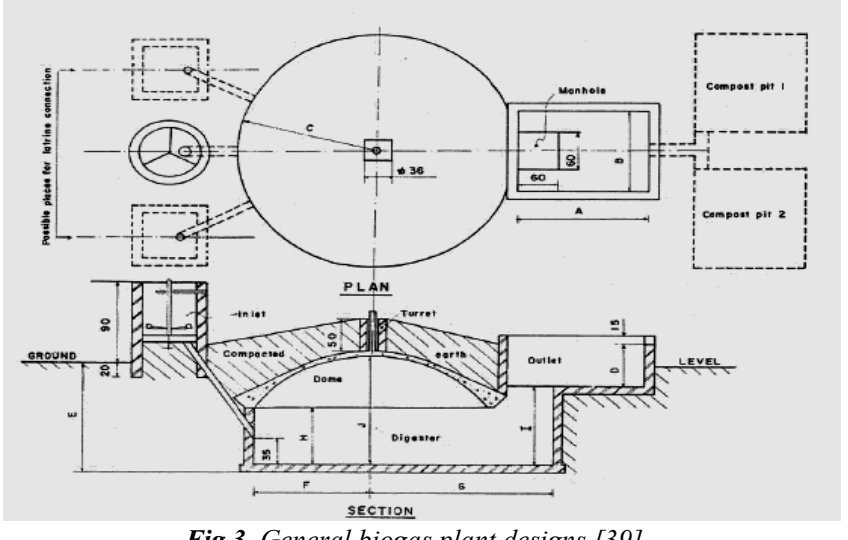

Fig 3. General biogas plant designs [39]

Table 1. Dimensions of 100cu.m fixed dome plant

\begin{tabular}{lll}
\hline Components & Symbol & Dimensions (cm) \\
\hline Length of outlet & A & 1150 \\
Breadth of outlet & B & 200 \\
Height of outlet & D & 100 \\
Radius of pit & C & 425 \\
Radius of digester & F & 365 \\
Height of digester wall & H & 310 \\
Depth of pit (excavation) & E & 400 \\
Height of dome & I-H & 30 \\
Height of outlet passage & I & 340 \\
Thickness of concrete dome & & 60 \\
Expansion canal & & Length $=22.5 \mathrm{~m}$, depth $=50 \mathrm{~cm}$ \\
\hline
\end{tabular}

Cost benefit analysis has been done using net present value (NPV) pay back times and internal rate of return.

$$
\mathrm{NPV}=\mathrm{R} \times \frac{1-(1+\mathrm{i})^{-\mathrm{n}}}{\mathrm{i}}-\text { Initial Investment }
$$

The benefits are calculated based on replacement ratio of biogas and commonly used Eucalyptus wood. It has been suggested that $1 \mathrm{cu} . \mathrm{m}$ biogas replaces $1.3 \mathrm{~kg}$ fire wood [1]. Amount of fire wood replaced,

$30 * 1.3=39 \mathrm{~kg}$ wood $/$ day

Market survey indicates $20 \mathrm{~kg}$ wood costs $30 \mathrm{birr}$ giving a ratio of $1.5 \mathrm{birr} / \mathrm{kg}$ wood.

Monthly saving is then,

$39 \mathrm{~kg} /$ day $* 1.5 \mathrm{birr} / \mathrm{kg} * 30$ days $=1755 \mathrm{birr} /$ month
Assuming 30cu.m/day gas is available for 10 months a year due to lower gas production during rainy season, Annual saving is 17,550birr [2].

In $2008 / 2009$ the faculty spent 39,424 .76birr. Hence this saving represent a reduction of $44.5 \%$ cost due to wood considering electricity irregularity at the time. The useful life time of a biogas plant is up to 40 years but the economic life time is 20 years since the value of benefit discounted to present time for time after 20 years is negligible. The discount rate has been taken to be the bank interest rate of $4 \%$. Other maintenance costs include cleaning of the digester every four years which is typical time based on experience on homogenous human waste digesters. Based on current lorry costs 1,000birr is required for cleaning.

Table 2. Bill of quantities and cost estimation

\begin{tabular}{|c|c|c|c|c|c|}
\hline Description & Unit & Quantity & $\begin{array}{l}\text { Unit price } \\
\text { Birr/unit }\end{array}$ & Total cost birr & $\begin{array}{l}\text { Transport cost } \\
\text { birr }\end{array}$ \\
\hline Block & Pcs & 1446 & 5 & 7,230 & 2,000 \\
\hline Cement & Quintal & 68 & 300 & 20,400 & 1,500 \\
\hline Sand & Cu.m & 30 & 185.71 & 5950 & 800 \\
\hline Stone & Cu.m & 72 & 52 & 3744 & 2,000 \\
\hline Gravel & Cu.m & 7 & 230 & 1610 & 400 \\
\hline Rc bar 10 & Pcs & 33 & 152 & 5016 & 200 \\
\hline Engine oil & Lit & 8 & 25 & 200 & \\
\hline
\end{tabular}




\begin{tabular}{|c|c|c|c|c|}
\hline Wax & $\mathrm{Kg}$ & 4 & 40 & 160 \\
\hline Gas pipe & $\mathrm{m}$ & 250 & 30 & 7,500 \\
\hline Slurry collector pipe & $\mathrm{m}$ & 130 & 30 & 3,900 \\
\hline Stoves & no & 4 & 600 & 2,400 \\
\hline Various fitting s & Pcs & 22 & & 889 \\
\hline Masonry & Days & 50 & 450 & 22,500 \\
\hline Labor & Days & 5 & 30/person/day & 9,000 \\
\hline Supervision & Days & 15 & 375 & 5,625 \\
\hline Excavation & Days & $10(10$ people $)$ & 30/person/day & 3,000 \\
\hline Total & \multicolumn{4}{|c|}{110,000 birr } \\
\hline
\end{tabular}

Payback time N (yrs), N =110,000/17,550, N=6.27years NPV calculation shows a value of 129,915 and internal rate of return $18.5 \%$

Larger and positive NPV and the IRR value indicate financial viabilities of the proposed project.

\section{Conclusions}

It has been found that installation of biogas plant leads to larger savings besides environmental and sanitation benefits. The gas thus produced replaced $44.5 \%$ of the cost due to wood. The economics of the system as evaluated by reliable Net present worth method proves a large and positive value indicating the attractiveness of the investment. This implies successful installation of this plant and similar others will prove to be economical in the face of rising number of students and fire wood scarcity and prices. Environmental values are immense as a waste from 4 blocks having 1000 people has been treated efficiently as compared to septic tanks and direct disposal. This contributes a lot in environmental protection and sanitation efficiency. Also the gas produced replaces significant amount of wood contributing to reduced deforestation. If similar projects are installed in all universities, its impact on the forest protection will be well vivid. The bio fertilizer thus produced can be used for plantations and gardens found in the faculty. This has dual benefit in the sludge management and bio-fertilizer utilization. It can further open a window of opportunity in introducing bio-fertilizer for the local famers around Bahirdar.

Installation of the plant is highly recommended due to its financial and environmental benefits. Similar applications in other Universities contribute a lot in realizing its economical benefits. It leads to forest savings, energy self dependency and efficient resource utilization. The university can be a model in renewable energy and energy self sufficiency if more efforts are made to exploit the abundant resources (including cafeteria waste) and the warm climate of Bahir-dar which creates favorable condition for microbial processes.

\section{Acknowledgement}

Author acknowledge to Department of Chemical Engineering for providing funding and facilities.

\section{References}

[1] Information and advisory service on appropriate technology (ISAT) and GTZ biogas application and product development, Biogas digest Vol. II

[2] ISAT/GTZ Biogas program implementation, Biogas digest Vol. III.

[3] EPA decentralized technology fact sheet, septic tank systems, united stated environmental protection agency, September 2000.

[4] Embassy of republic of Finland, report on biogas projects evaluation, March 2007, P.O.Box 4661, Addis Ababa, Ethiopia.

[5] Perez, M., Romero L.I., Sales D. 1997. Steady state anaerobic thermophilic degradation of distillery wastewater in fluidized bed bioreactors. Biotechnology Progress, 13: 33-38.

[6] Gallert, C., Henning, A., Winter, J. 2003. Scale-up of anaerobic digestion of the biowaste fraction from domestic wastes. Water Res., 37: 1433-1441.

[7] Forster-Carneiro, T., Pérez García, M., Romero García, L.I. 2007a. Composting potential of different inoculum sources on modified SEBAC system treatment of municipal solid wastes. Bioresource Technology, 98 (17): 3354-3366.

[8] Nguyena, P.H.L., Kuruparana, P., Visvanathan, C. 2007. Anaerobic digestion of municipal solid waste as a treatment prior to landfill. Bioresource Technology, 98(2): 380-387.

[9] Bouallagui H., Ben Cheikh R., Marouani L. and Hamdi M. 2003. Mesophilic biogas production from fruit and vegetable waste in a tubular digester, Bioresour. Technol., 86:85-89.

[10] Perez, M., Romero, L.I., Cano, R., Sales, D. 2005. Effect of ph influent conditions in fixed-film reactors for anaerobic thermophilic treatment of wine-distillery wastewaters. Water Science Technology, 51(1):183-189.

[11] Zabranska J, Dohanyos M, Jenicek P, Kutil J. 2000. Thermophilic process and enhancement of excess activated sludge degradability- Two ways of intensification of sludge treatment in Prague central wastewater treatment plant. Water Sci. Technol., 41:265-272.

[12] Mace, S., Dosta, D., Bolzonella, D., Mata-Alvarez, J. 2005. Full sacle implementation of AD Technology to treat the organic fraction of municipal solid waste in Spain. 4th 
International Symposium of Anaerobic digestion of Solid Waste (Copenhagen Denmark), 1:34-51.

[13] O'Keefe, D.M., Chynoweth, D.P. 2000. Influence of the separation, Leachate recycle and aeration on treatment of municipal solid waste in simulated landfill cells. Bioresource Techno., 72:55-66.

[14] Pavan, P., Battistoni, P., Mata-Alvarez, J., Cecchi F., 2000. Performance of thermophilic semi-dry anaerobic digestion process changing the feed biodegradability. Water Sci. Technol., 41(3), pp. 75-82.

[15] Lissens G, Vandevivere P, De Baere L, Biey EM, Verstrae W. 2001. Solid waste digestors: process performance and practice for municipal solid waste digestion. Water Sci Technology, 44(8):91-102.

[16] Kim M., Ahn Y-H and Speece R.E. 2002. Comparative process stability and efficiency of anaerobic digestion; mesophilic vs. thermophilic, Water Research, 36: 43694385 .

[17] Kim S.W., Park J.Y., Kim J.K., Cho J.H., Chun Y.N., Lee I.H., Lee J.S., Park J.S. and Park D.H. 2000. Development of a modified three-stage methane production process using food wastes, Appl. Biochem. Biotechnology, 84-86: 731741.

[18] Ahring, B. 1992. Turn-over of acetate in hot springs at $70^{\circ} \mathrm{C}$. Proc. of Thermophililes: Science and Technology, Reykjavik, Iceland, 130.

[19] Hartmann, H, Ahring, B.K. 2005. Strategies for the anaerobic digestion of the organic fraction of municipal solid waste - An overview. 4th International Symposium of Anaerobic digestion of Solid Waste (Copenhagen-Denmark), $1: 34-51$.

[20] Tchobanoglous, G., Hilary, T., Vigil, S.A. 1997. Gestión integral de residuos sólidos. MCMXCIII- Mc Graw-Hill, Inc. $1007 \mathrm{p}$.

[21] Mata-Alverez, J., Viturtia, A. Llabres-Luengo, P., Cecchi, F. 1993. Anaerobic digestion of the Barcelona central market organic waste: experimental study. Bioresource Technol. 39:39-48.

[22] Bouallagui, H., Touhami, Y., BenCheikh, R., Hamdi, M. 2005. Bioreactor performance in anaerobic digestion of fruit and vegetable wastes. Proc. Biochem., 40: 989-995.

[23] Krzystek, L., Ledakowicz, S., Kahle, H.J., Kaczorek, K. 2001. Degradation of household biowaste in reactors. Journal of Biotechnology. 92:103-112.

[24] Kim S.W., Park J.Y., Kim J.K., Cho J.H., Chun Y.N., Lee I.H., Lee J.S., Park J.S. and Park D.H. 2000. Development of a modified three-stage methane production process using food wastes, Appl. Biochem. Biotechnology, 84-86: 731741.

[25] Rao, M.S., Singh, S.P. 2004. Bio energy conversion studies of organic fraction of MSW: kinetic studies and gas yieldorganic loading relationships for process optimization. Bioresource Technology, 95:173-185.
[26] Bonzonella, D., Pavan, P., Mace, S., Cecchi, F. 2005. Dry Anaerobic digestion of differently sorted organic municipal solid waste: a full scale experience. 4th International Symposium of Anaerobic digestion of Solid Waste (Copenhagen Denmark), 1:85-92.

[27] Poulsen, T.G. 2003. Anaerobic Digestion. Solid Waste Management, Ch. 5. Aalborg University, Aalborg, Denmark.

[28] Pos, J., teBoekhorst, R., Eaton, D., Walczak, B. and Pavlicik, V. 1981. Biogas Production From Animal Manure and Crop Residues \& Processes, Procedure, and Design. Technical Report 126-59, 1981. School of Engineering, Ontario Agricultural College, University of Guelph.

[29] Price, E.C. a nd Cheremisinoff, P.N. 1981. Biogas: Production \& Utilization. Ann Arbor Science Publishers, Inc. Ann Arbor, MI.

[30] Ahring, B.K. 1994. Status on Science and Application of Thermophilic Anaerobic Digestion. Water Science Technology, Vol. 30, No. 12: 241-249.

[31] El-Mashad, H.M., Zeeman, G., van Loon, W.K.P., Bot, G.P. and Lettinga, G. 2004. Effect of temperature and temperature fluctuation on thermophilic anaerobic digestion of cattle manure. Bioresource Technology, Iss. 95: 191 201.

[32] Earth Tech. 2002. Waste-Based Energy Feasibility Study. Report submitted to Municipality of Chatham-Kent. Project No. 55484, Earth Tech Canada Inc. Markham, ON.

[33] Kramer, J. 2002. Agricultural Biogas Casebook. Submitted to Great Lakes Regional Biomass Energy Program. Resource Strategies, Inc. Madison, WI.

[34] Persson, S.P.E., Bartlett, H.D., Branding, A.E., and Regan, R.W. 1979. Agricultural Anaerobic Digesters: Design and Operation. Bulletin 827, The Pennsylvania State University, College of Agriculture, Agriculture Experiment Station. University Park, PA.

[35] AgSTAR. 2004. AgSTAR Handbook: A Manual for Developing Biogas Systems at Commercial Farms in the United States. Second Edition. U.S. Environmental Protection Agency and Environmental Restoration Group Inc.

[36] Timbers, G.E. and Marshall, D. 1981. Biogas as a Farm Energy Source. Contribution No. I-297. Engineering and Statistical Research Institute, Research Branch, Agriculture Canada.

[37] Barker, J.C. 2001. Methane Fuel Gas from Livestock Wastes: A Summary. Publication No. EBAE 071-80, North Carolina Cooperative Extension Service.

[38] Technical Guide for biodigester 2012. Selam technical and vocational training center (STVC), P.O.Box 26, Addis Ababa, Ethiopia

[39] Sunder Bajgain, 2011, Construction Manual for GGC2047 model biogas plant, Nepal. 